\title{
Dynamics of Dry-Down in Seed, Head and Stalk from Sunflower Genotypes Sprayed with Chemical Desiccants After Physiological Maturity
}

\author{
Cyntia L Szemruch ${ }^{1 *}$, Federico García ${ }^{2}$, Sebastian Zuil ${ }^{3}$, Christian Teysseire ${ }^{4}$, \\ Juan P Renzi ${ }^{5}$, Miguel A Cantamutto ${ }^{6}$, Santiago Renteria ${ }^{7}$, Deborah P Rondanini ${ }^{8}$ \\ 1*Facultad de Ciencias Agrarias, Universidad Nacional de Lomas de Zamora. Ruta 4 Km 2, Llavallol, Argentina \\ Corresponding author, E-mail: cyntiasz@yahoo.com.ar, ORCID: https://orcid.org/0000-0001-7504-5076 \\ ${ }^{2}$ IIPAAS Instituto de Investigación sobre Producción Agropecuaria, Ambiente y Salud. Facultad de Ciencias Agrarias, Universidad \\ Nacional de Lomas de Zamora. Ruta $4 \mathrm{Km}$ 2, Llavallol, Argentina, E-mail: federicoaugustogarcia@hotmail.com \\ ${ }^{3}$ EEA Reconquista, INTA. Instituto Nacional de Tecnología Agropecuaria. Ruta $11 \mathrm{Km} \mathrm{773,} \mathrm{Santa} \mathrm{Fe,} \mathrm{Argentina.}$ \\ E-mail: zuil.sebastian@inta.gob.ar, ORCID: https://orcid.org/0000-0002-3244-5990 \\ ${ }^{4}$ EEA Hilario Ascasubi, INTA. Instituto Nacional de Tecnología Agropecuaria. Ruta 3 Km 794, Buenos Aires, Argentina \\ E-mail: teysseire.christian@inta.gob.ar \\ ${ }^{5}$ EEA Hilario Ascasubi, INTA. Instituto Nacional de Tecnología Agropecuaria. Ruta 3 Km 794, Buenos Aires, Argentina \\ E-mail: renzipugni.juan@inta.gob.ar,ORCID: https://orcid.org/0000-0002-1431-7776 \\ ${ }^{6}$ EEA Hilario Ascasubi, INTA. Instituto Nacional de Tecnología Agropecuaria. Ruta 3 Km 794, Buenos Aires, Argentina \\ E-mail: mcantamutto@yahoo.com,ORCID: https://orcid.org/0000-0002-6854-7497 \\ ${ }^{7}$ Advanta Semillas SACI. Ruta 33 KM 636, Venado Tuerto, Santa Fe, Argentina, E-mail: sjrente73@gmail.com \\ ${ }^{8}$ Facultad de Ciencias Agrarias, Universidad Nacional de Lomas de Zamora. Ruta 4 Km 2, Llavallol, Argentina \\ E-mail: rondanin@agro.uba.ar, ORCID: https://orcid.org/0000-0003-0797-2497
}

\begin{tabular}{|c|c|}
\hline A R T I C L I N F O & A B S T R A C T \\
\hline $\begin{array}{l}\text { Keywords: } \\
\text { Paraquat } \\
\text { Carfentrazone } \\
\text { Saflufenacil } \\
\text { Seed moisture } \\
\text { Seed germination }\end{array}$ & $\begin{array}{l}\text { Chemical desiccation can advance the sunflower harvest time. Paraquat has been extensively used, } \\
\text { but other less risky chemicals, as Carfentrazone and Saflufenacil, can rise as an alternative. } \\
\text { Moisture levels of seed, head and the upper portion of stalk are all relevant for mechanical } \\
\text { harvesting, but dry-down dynamics of each tissue is unknown. The aim was to study the dry-down } \\
\text { dynamics of seed, head and stalk in sunflower genotypes sprayed with Paraquat, Carfentrazone } \\
\text { and Saflufenacil after physiological maturity. Seven experiments were carried out in the field in } \\
\text { Argentina (from } 29 \text { to } 39^{\circ} \mathrm{S} \text { ) during } 2014 / 2015 \text { and } 2015 / 2016 \text {. The genotypes used included } \\
\text { hybrids and female inbred lines of both oil and confectionery types. The dry-down of sunflower } \\
\text { plant was accelerated by desiccants with Paraquat, reducing seed and stalk moisture to a greater } \\
\text { extent. The head moisture remained very high ( }>80 \text { and } 70 \%) \text { during several days after application, } \\
\text { without differences among desiccants and control. Dynamics of seed, head, and stalk moisture } \\
\text { was not associated to vapor pressure deficit or meteorological conditions after chemical } \\
\text { application. Loss of green color of leaves was not a reliable indicator of seed dry-down dynamics. } \\
\text { Seed germination was not affected by chemical desiccation on either oil-type or confectionery } \\
\text { female plants. Under broad conditions of these experiments, the Paraquat was effective for } \\
\text { seeds/grains and stalks drying in both sunflowers hybrids and inbred lines. The slowly drying of } \\
\text { heads makes it necessary to continue investigating with new doses and combinations of desiccants } \\
\text { to ensure an optimal harvest. Desiccants were safe for seed germination, which benefits their } \\
\text { usefulness in the seed industry. }\end{array}$ \\
\hline
\end{tabular}

\section{Introduction}

Sunflower is one of the four most important oil crops in the world and chemical desiccation can be used to advance the mechanical harvest time. This technique reduces the losses caused by exposure to weather, pathogens, bird attacks and improves harvest operation (Radić et al., 2006). Such technology has shown increasing importance along time, especially for intensified cropping systems and modern genotypes (Mc Naughton et al., 2015).

Chemical desiccants vary in composition and mode of action, with Paraquat (salt of 1, 1'-Dimethyl-4, 4'bipyridinium) being the most commonly used chemical in grain crops (Bellé et al., 2014). Paraquat exerts its phytotoxic effect by diverting electrons from photosystem
I (PSI) to molecular oxygen, resulting in a generation of $\mathrm{H}_{2} \mathrm{O}_{2}$ and hydroxyl radical, which interrupts photosynthesis and ruptures cell membranes (Chen et al., 2012). This allows water to leave the cells leading to rapid desiccation of foliage. In spite of these advantages, Paraquat has been banned in 32 countries because of acute toxicity risk (Chaneva and Petrova 2014). Thus, it is convenient to evaluate other alternative desiccants with less toxicological risk, such as Saflufenacil and Carfentrazone (Mc Naughton et al., 2015). Both desiccants act by inhibiting protoporphyrinogen IX oxidase (PPO) activity, causing rapid light-dependent wilting and necrosis of tissues (Grossmann et al., 2010). 
Several works have shown the effectiveness of Paraquat to accelerate the dry-down of different seeds (Johnson et al., 2004; Esahani et al., 2012), especially when plants are sprayed at high seed moisture level (40-50\%). Nevertheless, the effects of Saflufenacil and Carfentrazone on seed dry-down are scarce (Stahlman et al., 2010). In addition, it is important to identify the effects of chemical desiccants on other plant organs that are involved in the mechanical harvest, such as the head (inflorescence, receptacle) and the upper section of the stalk (Gubbels y Dedio, 1985). As a general rule, a minimum of $40 \%$ head moisture is allowed for an efficient mechanical harvest of sunflower (Howatt, 2011). If stalk and head enter the harvester with excessive moisture, they limit threshing and cleaning capacity (Johnson et al., 2004).

Some reports show that chemical desiccation decreases moisture of sunflower leaves, stalks and heads alike (Liović et al., 2008) while others indicate that head and stalk dry more slowly than seeds (Gubbels y Dedio, 1985; Stahlman et al., 2010). Differences found in the literature on dry-down dynamics of different organs could be related to genotypic characteristics, such as stay green trait (Barry, 2009; Johnson et al., 2004; Ongom et al., 2016). A second possibility could be related to the mode of action of each chemical desiccant, as was stated by Kleingartner (2010). Thirdly, environmental conditions during post-spraying time could also affect the dry-down dynamics in plants. As an example, re-hydration of tissues in sunflower under wet and rainy climate after spraying was observed by Stahlman et al. (2010) and Linz et al. (2015). So far, the effects of chemical desiccants on drying dynamics of different plant organs are not deeply known either for modern sunflower hybrids or parental oily and confectionery inbred lines. Also, associations between the dry-down dynamics of stalk and head with seed moisture have not yet been studied.

For sunflower seed production purpose, it is relevant to analyze possible detrimental effects of chemical desiccants sprayed on female plants of inbred lines on seed physiological quality. Paraquat proved not to damage the sunflower seed quality at harvest time (Szemruch et al., 2014) or during seed storage (Szemruch et al., 2015) but the effects of Saflufenacil and Carfentrazone chemical desiccants on sunflower seed germination are still unknown.

The aim of this work was to study the dry-down dynamics of sunflower seed, head and stalk in a range of hybrid and inbred line genotypes (including both oil and confectionery types) sprayed with Paraquat, Carfentrazone and Saflufenacil after physiological maturity. The hypotheses tested were (i) chemical desiccants are effective to accelerate the drying of head and stalk in a similar magnitude to seeds, (ii) chemical desiccants differ in their dry-down capacity, depending on genotypes and meteorological conditions after spraying, and (iii) chemical desiccants do not have a negative effect on seed germination.

\section{Materials and Methods}

\section{Genotypes and Experimental Details}

A total of seven experiments during 2014/2015 and $2015 / 2016$ were carried out in four locations covering the broad sunflower production area in Argentina. The genotypes used including commercial hybrids and female inbred lines of both oil and confectionery types (Table 1). Throughout the text, the sunflower fruits are named as grains, when it comes from commercial hybrids, and they are named as seeds when it comes from female inbred lines. Weather conditions from each experimental site are presented in Figure 1. Exp. 1 and 2 were carried out in Venado Tuerto, Santa Fe Province (33⒋ $4^{\prime} \mathrm{S}$; 61 ${ }^{\circ} 58^{\prime} \mathrm{W}$ ) in $1.5 \times 5 \mathrm{~m}$ plots (population density 5.0 plants $\mathrm{m}^{-2}$, rows separated by $0.7 \mathrm{~m}$, female:male ratio 2:3) on a Typic Argiudoll soil. An oil-type female line (IL01) was grown and manually pollinated with a proper restorer male. Exp. 3 and 4 were carried out in Hilario Ascasubi, Buenos Aires Province $\left(39^{\circ} 23^{\prime} \mathrm{S} ; 62^{\circ} 37^{\prime} \mathrm{W}\right)$ in $3.5 \times 40 \mathrm{~m}$, and $1.2 \times$ $20 \mathrm{~m}$, for treated and untreated plots, respectively, on an Ustic Torripsament soil. Population density at harvest was 6.1 and 4.7 plants $\mathrm{m}^{-2}$ for Exp. 3 and 4, respectively, rows separated by $0.7 \mathrm{~m}$, female: male ratio $4: 1$. A confectionery-type female line (L1) was grown and open pollinated. Exp. 5 and 6 were conducted at the School of Agronomy, University of Buenos Aires ( $34^{\circ} 35^{\circ} \mathrm{S} ; 58^{\circ} 26^{\prime}$ $\mathrm{W}$ ) in $2.1 \times 3 \mathrm{~m}$ plots (population density 5.7 plantsm $^{-2}$, rows separated by $0.7 \mathrm{~m}$ ) on a Typic Argiudoll soil. Traditional (Paraiso 20), stay-green (Syn 3825) and high oleic (Olisun 4) oil-hybrid genotypes were grown. Exp. 7 was conducted in Reconquista, Santa Fe Province (29 $26^{\prime}$ $\mathrm{S} ; 59^{\circ} 42^{\prime} \mathrm{W}$ ) in $10 \times 50 \mathrm{~m}$ plots (population density at 4.5 plants $\mathrm{m}^{-2}$, rows separated by $0.52 \mathrm{~m}$ ) on Aquertic Argiudoll soil. Traditional (Syn 3970) and high oleic (Syn $3950 \mathrm{HO}$ ) oil-hybrid genotypes were grown. Fertilization with $\mathrm{N}$ and $\mathrm{P}$ was applied according to soil analysis. Supplementary irrigation was applied in all experiments to avoid drought stress. Weeds, diseases and pests were chemically controlled. In Exp. 1-2 and 5-7, cloth bags of polyamide were used to cover heads from the beginning of grain filling (R6, Schneiter and Miller, 1981) in order to prevent bird damage.

\section{Chemical Desiccants}

Recommended commercial doses of Paraquat (paraquat dicloruro $27.5 \mathrm{~g}$ per $100 \mathrm{~g}$ at a dose of $2 \mathrm{~L} \mathrm{ha}^{-1}$ ), Carfentrazone (carfentrazone ethyl $40 \mathrm{~g}$ per $100 \mathrm{~mL}$ at a dose of $0.06 \mathrm{~L} \mathrm{ha}^{-1}$ ), and Saflufenacil (saflufenacil $70 \mathrm{~g}$ per $100 \mathrm{~g}$ at a dose of $60 \mathrm{~g} \mathrm{ha}^{-1}$ ) were used in the experiments (Table 1). All chemicals were dissolved in water and paraffinic mineral oil was used as adjuvant for carfentrazone and saflufenacil, according to manufacturer's recommendation. In Exp. 1-2 and 5-6 a knapsack sprayer was used, whereas a pulled sprayer and mechanical sprayer were used in Exp. 3-4 and 7, respectively. For all experiments, sprayers were equipped with hollow-cone nozzles and operated at 3 bar pressure for spraying over the top of plants. Untreated control plots of each genotype were also included in each experiment. Spraying was made around R7-R8 crop stage, with the back of head turning yellow (Schneiter and Miller, 1981). Seed moisture content at the time of desiccant application was about $37.3 \pm 0.7 \%$ (Exp. 1), 36.3 $\pm 1.3 \%$ (Exp. 2), $42.7 \pm 2.3$ (Exp. 3), $45.3 \pm$ $1.3 \%$ (Exp. 4), $15.0 \pm 1.6 \%$ (Exp. 5), $31.0 \pm 8.7 \%$ (Exp. 6), $38.6 \pm 0.8 \%$ (Exp. 7). Such broad range of seed moisture content is near sunflower physiological maturity, $38-40 \%$ seed moisture for oil-type (Rondanini et al., 2007) and 40-50 for confectionery - type (Guesh and Johnson, 2012) and it agrees with moisture levels commonly used by seed industry and farmers to anticipate harvest time. 
Table 1 Summary of experiments and chemical desiccants applied to sunflower genotypes in Venado Tuerto (VT), Hilario Ascasubi (HA), Buenos Aires (BA) and Reconquista (RE) locations from Argentina.

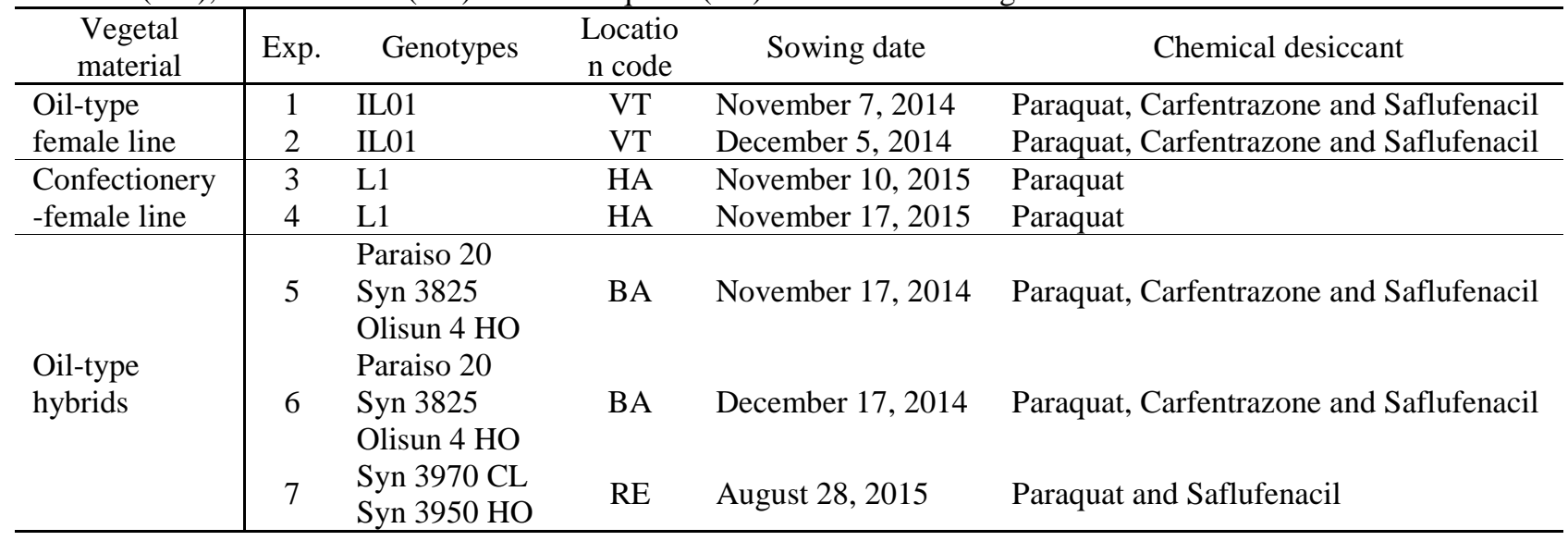

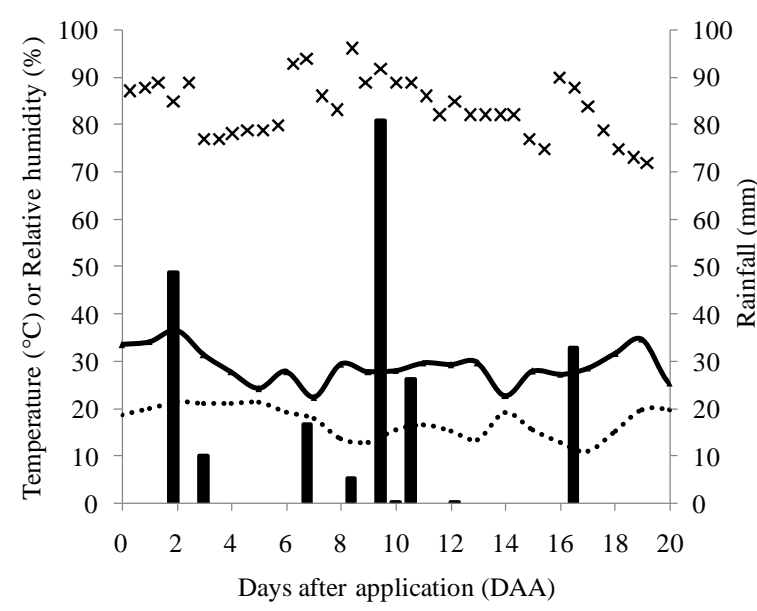

(a)

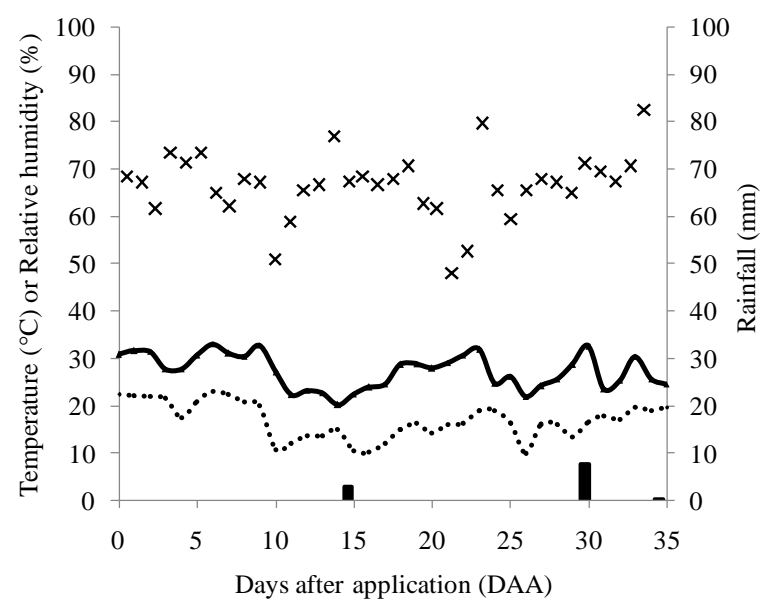

(c)

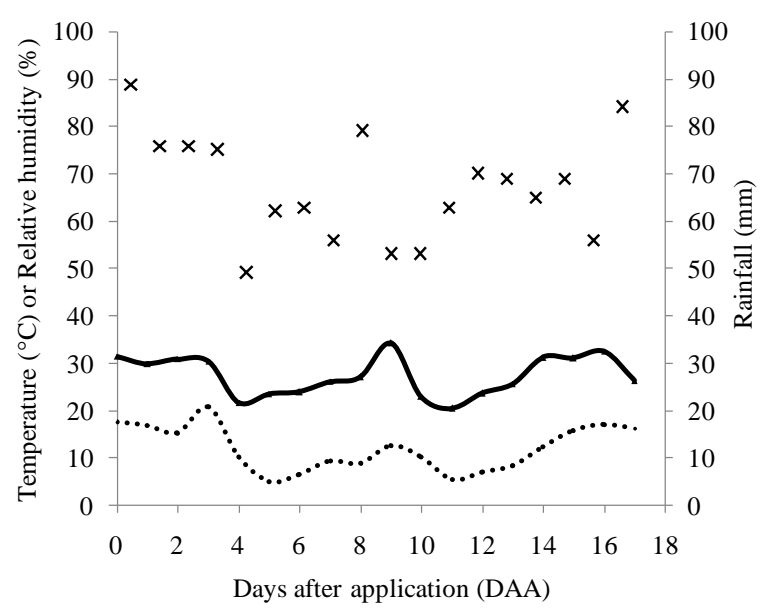

(b)

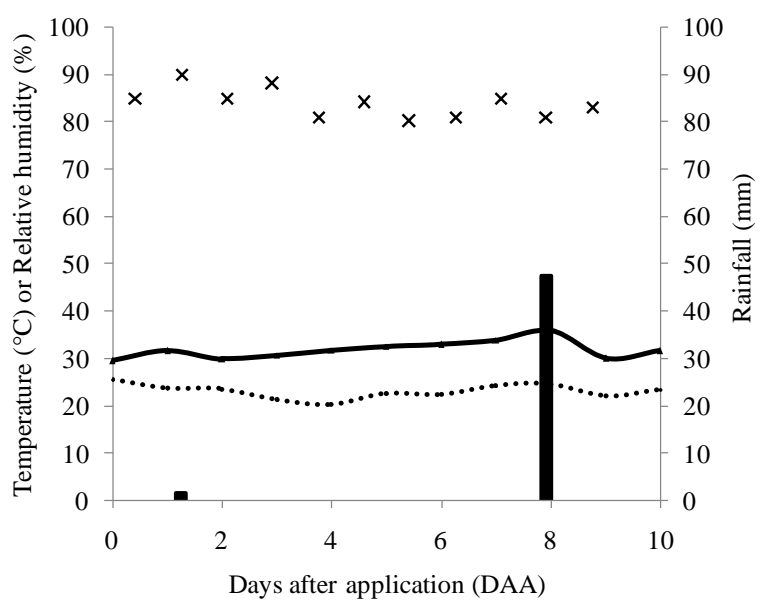

(d)

Figure 1 Minimum temperature (dotted lines), maximum temperature (continues lines), rainfall (blacks bars), and relative humidity (cross symbols) during days after chemical application (DDA) from locations Venado Tuerto (a),

Hilario Ascasubi (b), Buenos Aires (c) and Reconquista (d) included in this study

\section{Measurements}

Seed moisture (\% in a wet basis) at spraying time was measured by gravimetric method (ISTA, 2015) after drying at $105^{\circ} \mathrm{C}$ for $24 \mathrm{~h}$ on a sample of $120 \mathrm{~g}$ seeds, randomly picked from three (in Exp. 1-2 and 5-7) or two plants per plot (Exp. 3-4). Green colour from the top six leaves was measured twice a week using a chlorophyll meter SPAD502 Plus (Konica Minolta, Osaka, Japan). During the period of 12 or 24 days after spraying, two or six plants (depending on the experiment) were sampled twice a week. A sectional 1/8 of the floral inflorescence and the top 0.1 $\mathrm{m}$ of stalk (below the last leaf) were manually dissected. Thereafter seeds, head, and stalk were separated and moisture levels were measured by gravimetric method (by difference between fresh and dry weight) after drying at $60^{\circ} \mathrm{C}$ until obtaining a constant weight. In the Exp. 1 and 2 , seed germination was measured during 2-24 days after 
application (DDA) and 2-12 DDA, respectively, after applying a dormancy-breaking treatment (pericarp and seed coat manual removal) according to Szemruch et al. (2014). Four replicates of 50 seeds were incubated between paper substrate at $25^{\circ} \mathrm{C}$ with 12 hours light/12 hours dark (ISTA, 2013). The paper properties were white colour, 40.9 $\mathrm{g} / \mathrm{m}^{2}$ and $360 \times 220 \mathrm{~mm}$ size. For Exp. 3-4, seed germinations were determined at 31 DDA on four replicates of 50 seeds incubated on sand substrate at 20/30 ${ }^{\circ} \mathrm{C}$ with 12 hours light/12 hours dark (ISTA, 2013). On the $10^{\text {th }}$ day after starting the test, the seeds were classified as germinated (normal and abnormal seedlings), dead or fresh. Meteorological data (rainfall, air temperature and relative humidity) during the days after chemical application were obtained from weather stations placed near each experimental location (Fig. 1). Vapor pressure deficit was calculated from mean daily temperature and mean daily relative humidity data, according to Allen et al. (1998).

\section{Experimental Design and Statistical Analysis}

Experimental design was DCA with 3 replicates (Exp. 1-2) and 4 replicates (Exp. 3-4). Exp. 5-6 were conducted as DCA with 2 replicates, with a factorial arrangement of genotypes and desiccants. Exp. 7 was a split-plot design with 3 replicates, randomizing genotypes in the main plot and desiccants in the sub-plot. For each experiment, ANOVA and Tukey's test were applied to separate means, with a significance of 5\%. Angular transformation was applied to percentage data. Correlation analysis was applied to seed moisture content and vapor pressure deficit dynamics. Mean values $\pm 1 \mathrm{SD}$ are given in the text. Data were analysed by Infostat Software Program (Di Rienzo et al., 2011). In the figures, two points differ significantly when the standard error bars do not touch each other (Cumming et al., 2007). It is possible that some error bars are not visible because they are smaller than the chosen symbol size.

\section{Results}

Dry-Down of Seed, Head and Stalk from Oil and Confectionery Female Inbred Lines (Experiments 1 To 4)

Seed dry-down was accelerated by chemical desiccant with respect to Control, especially at 6-16 days after application (DDA) in Exp 1, 4-8 DDA in Exp 2 and 2-8 DDA in Exp. 3 (Fig. 2). Paraquat reduced seed moisture to a greater extent, whereas Saflufenacil and Carfentrazone exhibited lower and later effects (Fig. 2).

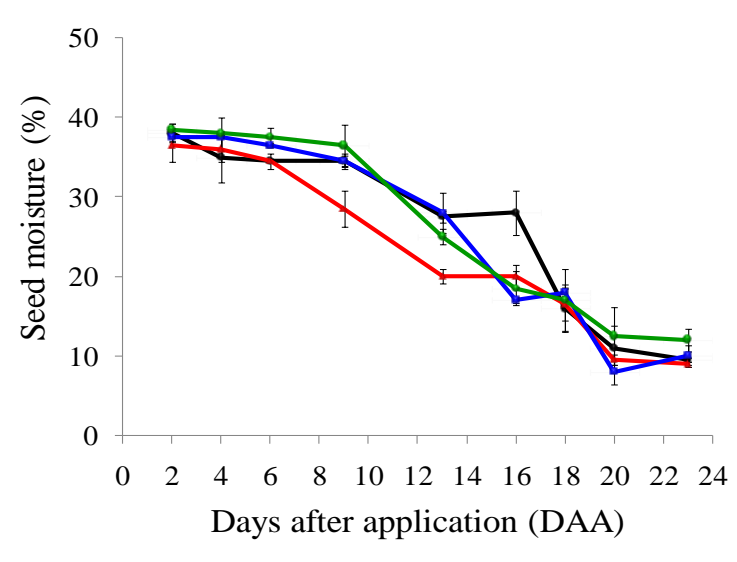

(a)

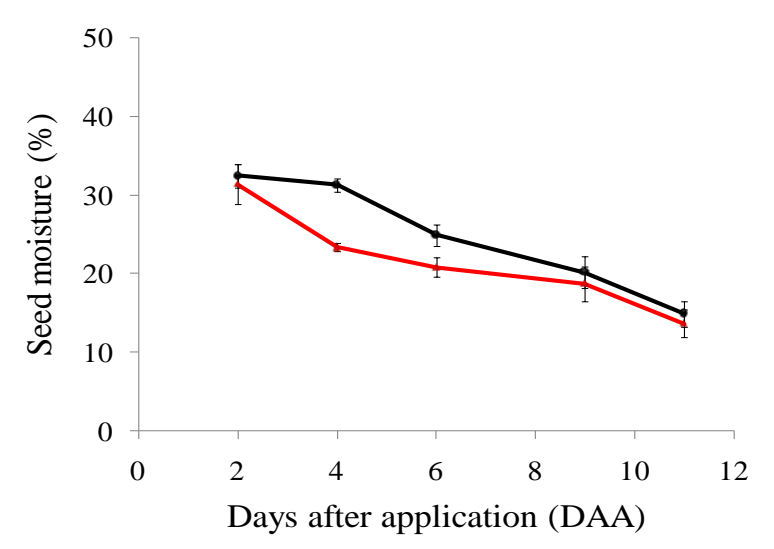

(c)

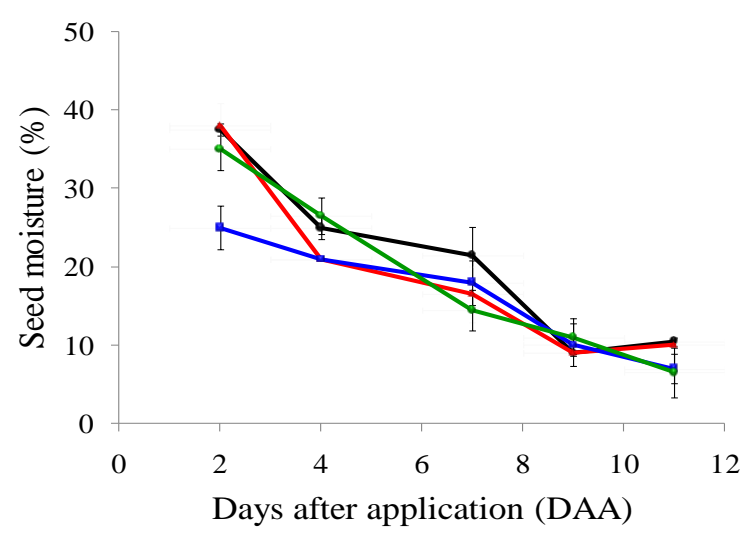

(b)

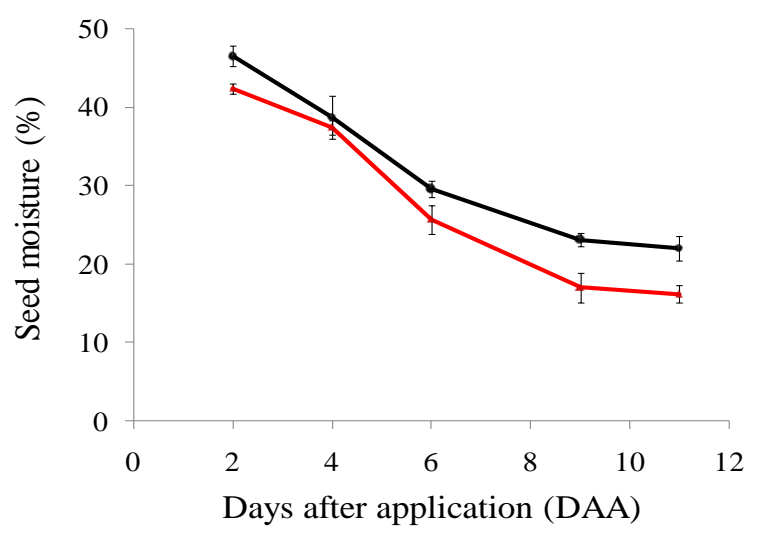

(d)

Figure 2 Dynamics of seed moisture of sunflower female lines sprayed with chemical desiccant Paraquat (red line), Saflufenacil (blue line), Carfentrazone (green line) and Control without desiccant (black line) from Exp. 1 (a), 2 (b),

3 (c) and 4 (d). Vertical bars indicate \pm 1 SD. Two points differ significantly when the standard error bars do not touch each other. See details of female lines and experimental years in Table 1. 


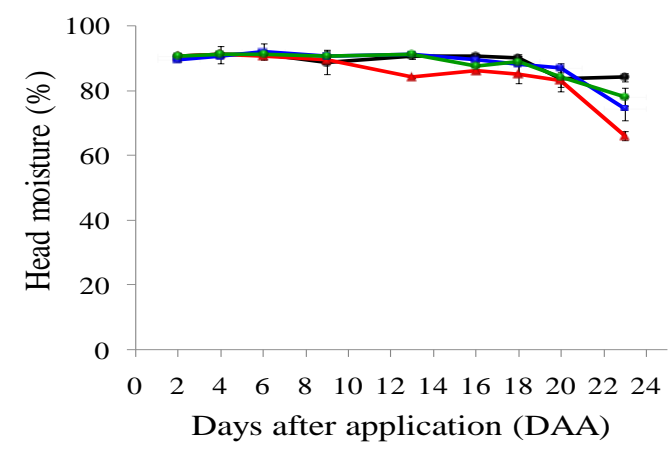

(a)

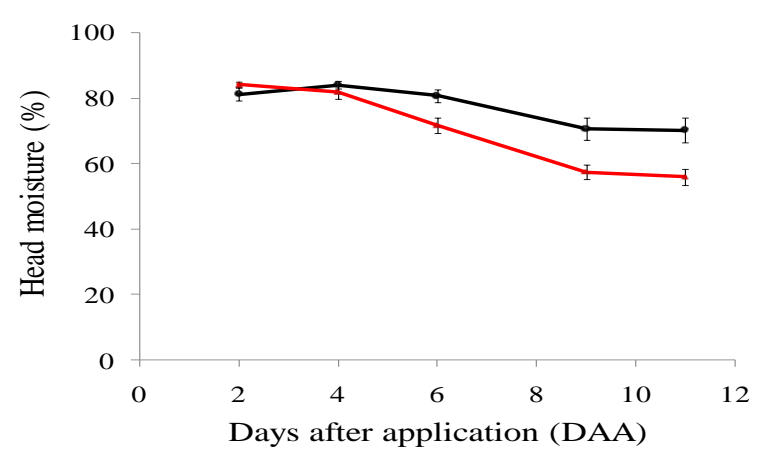

(c)

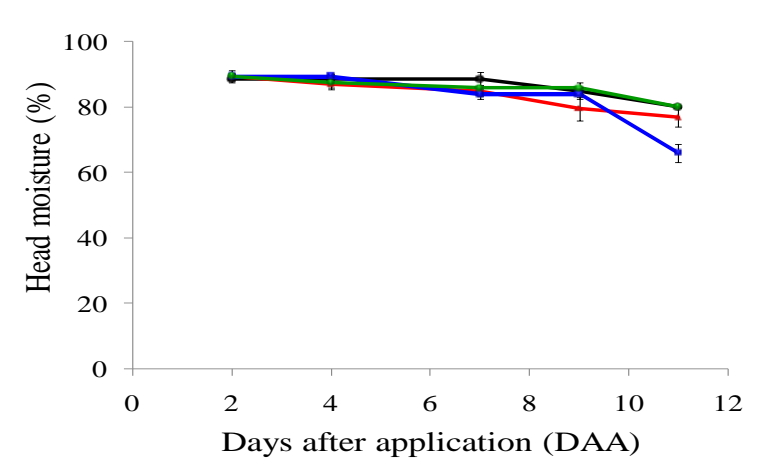

(b)

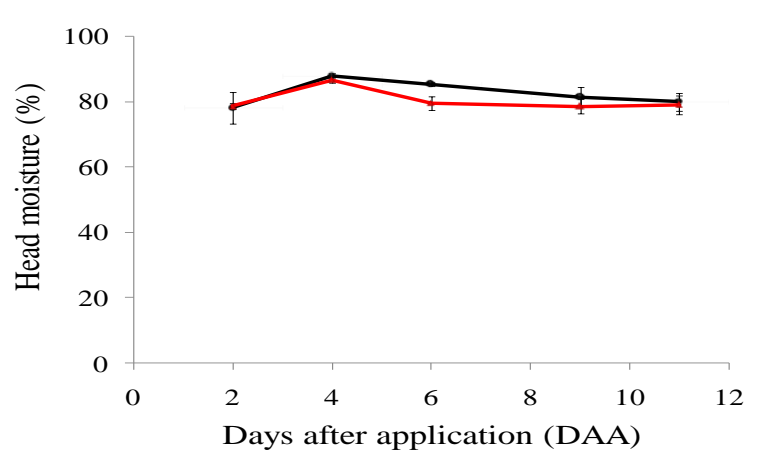

(d)

Figure 3 Dynamics of head moisture of sunflower female lines sprayed with chemical desiccant Paraquat (red line), Saflufenacil (blue line), Carfentrazone (green line) and Control without desiccant (black line) from Exp. 1 (a), 2 (b),

3 (c) and 4 (d). Vertical bars indicate \pm 1 SD. Two points differ significantly when the standard error bars do not touch each other. See details of female lines and experimental years in Table 1.

Unlike seeds, head moisture remained very high (>80\%) during several days for all treatments (Fig. 3). Significant effects of desiccants were observed late for Paraquat, from 20 DDA (Exp. 1) or 8-6 DDA (Exp. 2 and 3 ), and very late for Saflufenacil at 11 DDA only from Exp. 2 (Fig. 3). In a similar way, stalk moisture remained very high $(>70 \%)$ during several days without differences among treatments (Fig. 4). Subsequently, Paraquat showed a strong effect, reducing stalk moisture by approximately $50 \%$ with respect to controls in all experiments (Fig. 4) and Saflufenacil also showed a significant effect in Exp. 1 and 2 (Fig.4).

When head and stalk moisture were related to seed moisture, a similar pattern was observed for all experiments (Fig. 5). As the seeds dried, head moisture remained very high $(>65 \%)$ without significant differences between treatments and controls. Considering that crop harvesting for seed industry purpose can be done with 15$30 \%$ seed moisture, in all experiments this range coincided with head moisture $>65 \%$, even using chemical desiccants (Fig. 5 a, c). Stalk moisture reduction was notorious from a seed moisture level around $22 \%$ in Exp. 1-2 (Fig. 5 b) and $30 \%$ in Exp. 3-4 (Fig. 5 d). When seed moisture reached $15 \%$ (lower limit for seed harvest), stalk moisture levels of desiccant treatments were about $70 \%$ and $45 \%$, in Exp. 1-2 and 3-4, respectively (Fig. 5 b, d).

Dry-Down of Seed, Head and Stalk from Oil-Type Sunflower Hybrids (Experiments 5 To 7)

All oil-type sunflower hybrids from Exp. 5-7 exhibited dynamics of grain, head and stalk moisture with a trend similar to that observed for inbred lines (Fig. 6). When grain moisture was $15 \%$, head and stalk moisture remained very high (> 60 and $65 \%$, respectively) including desiccant treatments (Fig. 6). There were no relevant differences in dry-down dynamics among hybrids, including stay green, traditional and high-oleic types (Fig. 6).

Association Between Dry-Down Dynamics and Meteorological Conditions for Female Inbred Lines and Hybrids (Experiments 1 To 7)

Meteorological conditions after chemical application were not associated to dry-down dynamics, with the exception of a significant correlation between head moisture and the relative humidity of air from Exp. 7 $(\mathrm{r}=0.70, \mathrm{p}=0.02)$. Dynamics of seed/grain, head, and stalk moisture were not associated to vapor pressure deficit, calculated from mean daily temperature and mean daily relative humidity (data not shown).

Effects of Chemical Desiccants on Leaf Coloration from Oil-Type Sunflower Hybrids (Experiment 6)

Green coloration of the upper leaves softened as grain moisture decreased, but it was a poor indicator of grain moisture, as a broad range of grain moisture corresponds to the absolute lack of green color (Fig. 7). For Paraiso 20 and Syn 3820 hybrids (without and with stay-green, respectively) chemical desiccant did not affect the loss of green color (Fig. 7 a, b). By contrast, Olisun 4 (high oleic type) showed less green coloration for Paraquat with respect to Control (Fig. 7 c). Although all chemical desiccants caused necrosis on the back of heads (see supplementary material), it was not associated to a faster dry-down of head or stalk (both having moisture $>60 \%$ ). 


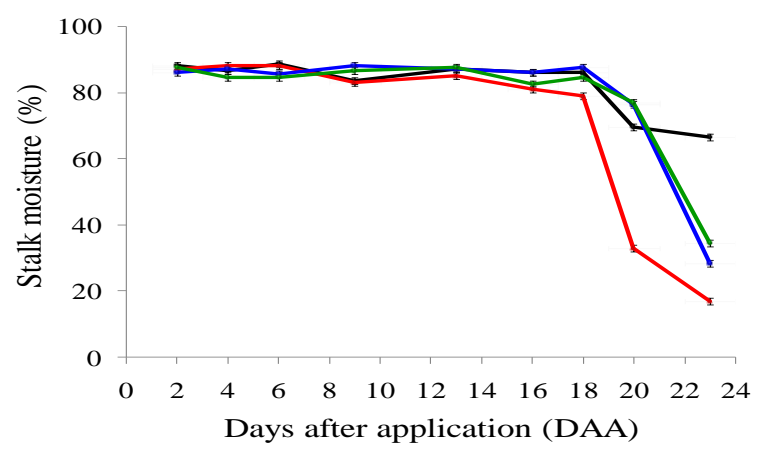

(a)

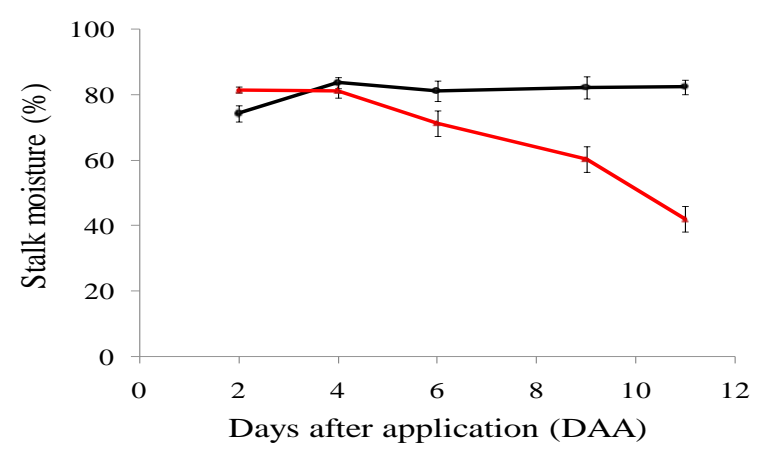

(c)

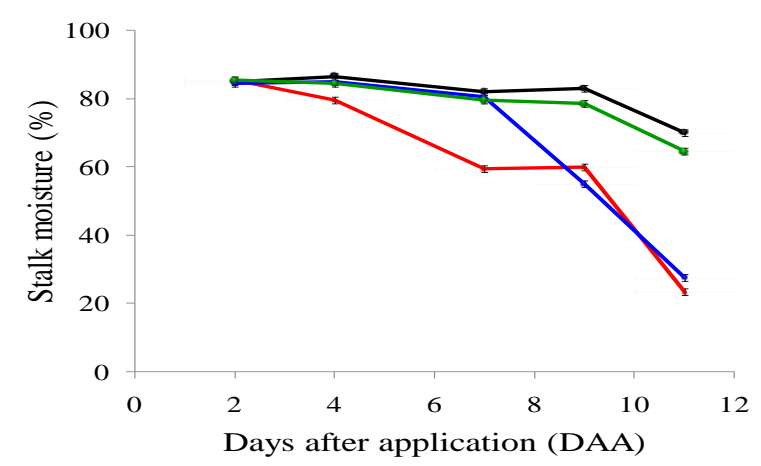

(b)

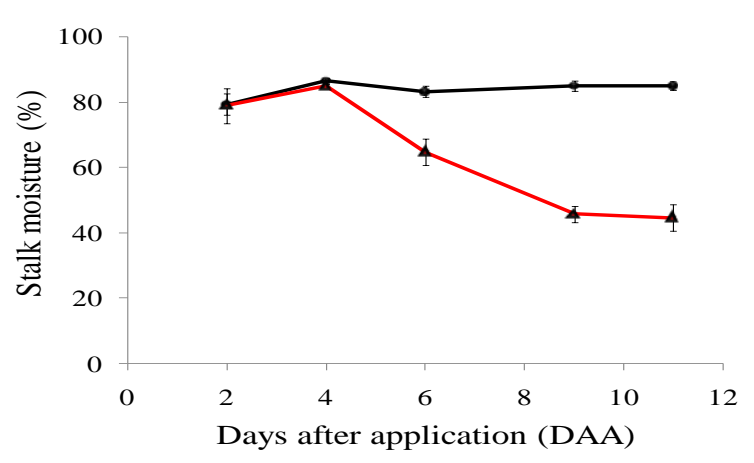

(d)

Figure 4 Dynamics of stalk moisture of sunflower female lines sprayed with chemical desiccant Paraquat (red line), Saflufenacil (blue line), Carfentrazone (green line) and Control without desiccant (black line) from Exp. 1 (a), 2 (b), 3 (c) and 4 (d). Vertical bars indicate \pm 1 SD. Two points differ significantly when the standard error bars do not touch each other. See details of female lines and experimental years in Table 1.

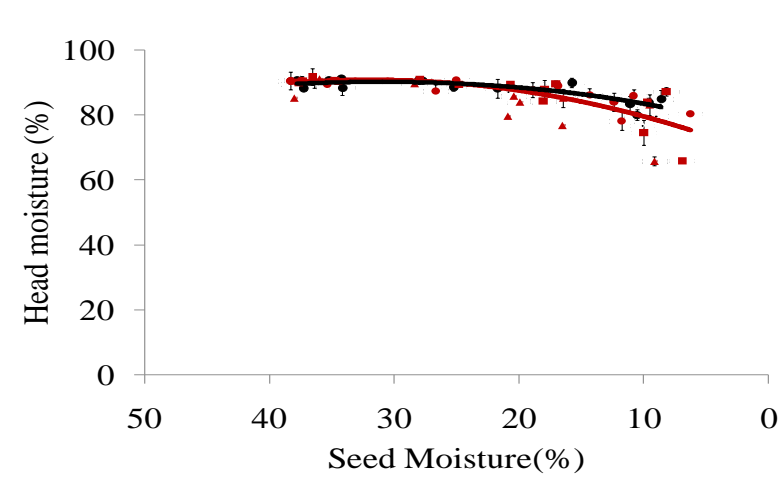

(a)

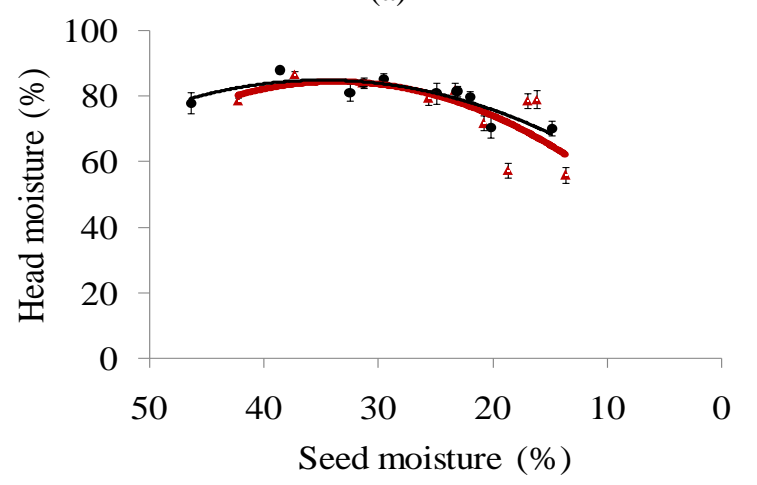

(c)

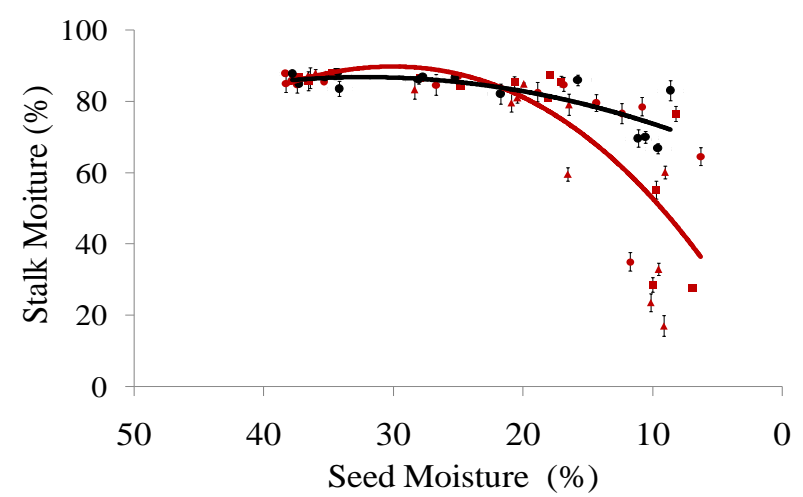

(b)

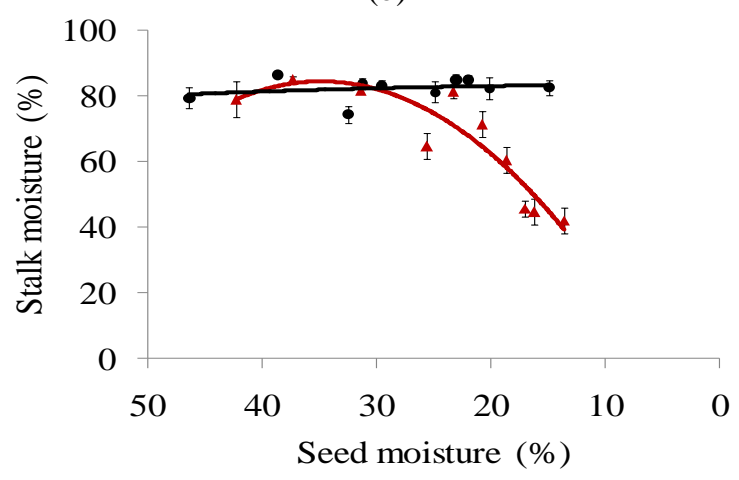

(d)

Figure 5 Dynamics of head (left panel) and stalk (right panel) moisture as a function of grain moisture content of sunflower female lines sprayed with chemical desiccant Paraquat (red triangle), Saflufenacil (red square),

Carfentrazone (red circle) and Control without desiccant (black circle) from Exp. 1 y 2 (a, b) y Exp. 3 y 4 (c, d).Vertical bars indicate \pm 1 SD. Two points differ significantly when the standard error bars do not touch each other. See details of female lines and experimental years in Table 1. 


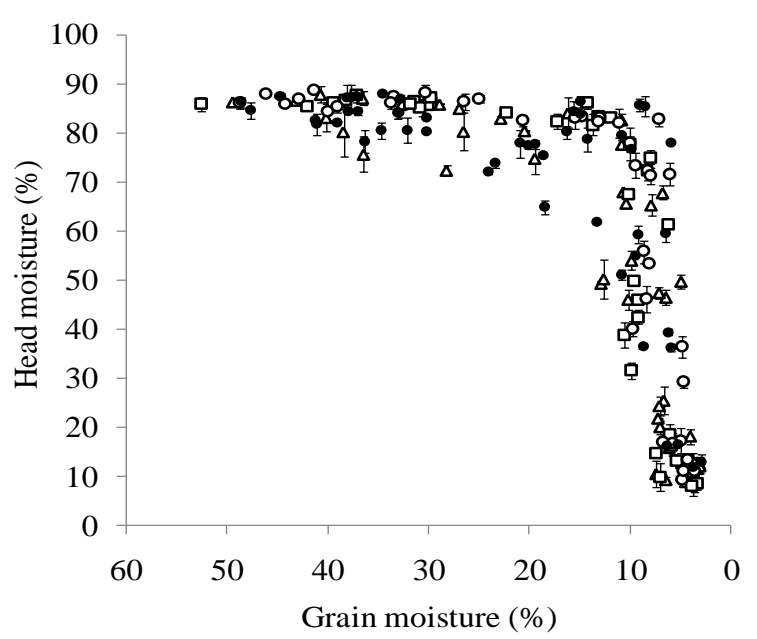

(a)

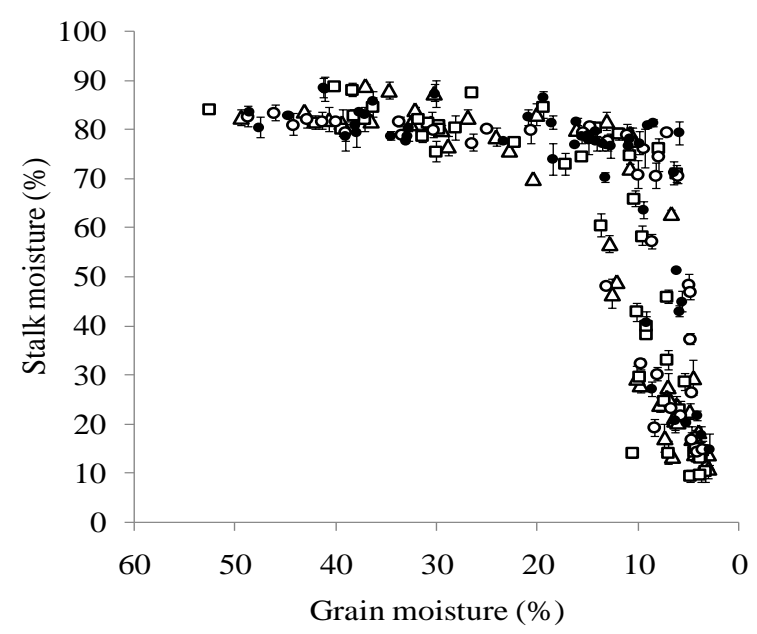

(b)

Figure 6 Dynamics of head (a) and stalk (b) moisture as a function of seed moisture content of sunflower oil-type hybrids sprayed with chemical desiccant Paraquat (empty triangle), Saflufenacil (empty square), Carfentrazone (empty circle) and Control without desiccant (black circle) from Exp. 5-7. Vertical bars indicate \pm 1 SD. Two points differ significantly when the standard error bars do not touch each other. See details of hybrids and experimental years in Table 1.

Table 2 Seed germination (\%) at different days after application (DDA) of chemical desiccants to sunflower female inbred lines from Exp. 1 and 2. See details of female lines and experimental years in Table 1. Significant differences among desiccants (capital letters) and DDA (lower case letters) are presented where $\mathrm{P} \leq 0.05$.

\begin{tabular}{|c|c|c|c|c|c|}
\hline \multirow{2}{*}{ Exp. } & \multirow{2}{*}{ Treatment } & \multicolumn{4}{|c|}{ DDA } \\
\hline & & 2 & 6 & 9 & 23 \\
\hline \multirow{5}{*}{1} & Control & $97^{\mathrm{Aa}}$ & $98^{\mathrm{Aa}}$ & $98^{\mathrm{Aa}}$ & $97^{\mathrm{Aa}}$ \\
\hline & Paraquat & $97^{\mathrm{Aa}}$ & $98^{\mathrm{Aa}}$ & $99^{\mathrm{Aa}}$ & $93^{\mathrm{Aa}}$ \\
\hline & Saflufenacil & $98^{\mathrm{Aa}}$ & $95^{\mathrm{Aa}}$ & $96^{\mathrm{Aa}}$ & $95^{\mathrm{Aa}}$ \\
\hline & Carfentrazone & $97^{\mathrm{Aa}}$ & $97^{\mathrm{Aa}}$ & $98^{\mathrm{Aa}}$ & $97^{\mathrm{Aa}}$ \\
\hline & & 2 & 7 & 9 & 11 \\
\hline \multirow{4}{*}{2} & Control & $100^{\mathrm{Aa}}$ & $91^{\mathrm{Ba}}$ & $95^{\mathrm{Aa}}$ & $92^{\mathrm{Aa}}$ \\
\hline & Paraquat & $96^{\mathrm{Ba}}$ & $96^{\mathrm{ABa}}$ & $97^{\mathrm{Aa}}$ & $88^{\mathrm{Aa}}$ \\
\hline & Saflufenacil & $100^{\mathrm{Aa}}$ & $96^{\mathrm{ABa}}$ & $93^{\mathrm{Aa}}$ & $90^{\mathrm{Aa}}$ \\
\hline & Carfentrazone & $95^{\mathrm{Ba}}$ & $99^{\mathrm{Aa}}$ & $90^{\mathrm{Aa}}$ & $78^{\mathrm{Ba}}$ \\
\hline
\end{tabular}

Effects of Chemical Desiccants on Seed Germination (Experiments 1 And 2)

Seed germination was not affected by chemical desiccation of oil-type female plants in Exp. 1-2 (Table 2) exhibiting seed germination values within commercial standard for seed industry ( $>85 \%)$, with the only exception of Carfentrazone at 11 DDA in Exp. 2 (Table 2). Seed germination did not vary for confectionery inbred female line either, as seed germination at 31 DDA was $91-97 \%$ for Controls, and 94-96\% for Paraquat, for Exp. 3 and 4, respectively (data not shown).

\section{Discussion}

The set of seven experiments analyses revealed differences in the drying dynamics between the chemical desiccants and the plant organs. Although responses to more environmentally safe desiccants, as Saflufenacil, were obtained, Paraquat was the active ingredient which had the highest desiccant effect on most organs and experiments. A high effectiveness for the drying of sunflower with Paraquat was also observed by Stahlman et al. (2010).
As observed by Esfahani et al. (2012) and Toledo et al. (2012), the water loss was different according to the organ and the time from drying. Seeds/grains began to dry on the first days after application (2 - 16 DDA). Although the greatest differences in moisture between treatments and control occurred in the intermediate stage of drying, they were equalized towards its end (Fig. 2). Given that no significant correlations were found between the seeds/grains moisture and meteorological variables, their greater response to desiccation could be due to the physical characteristics of the seed tissues. The movement of water could be regulated by the amount of waxes cuticle (Schreiber and Riederer, 1996; Franchini et al., 2008; Fernández et al., 2017), the variations in the thickness of the pericarp, or its separation from the seed (Denis et al., 1994; Mantese et al., 2006).

The heads and stems dried several days later than the seeds/grains, starting at 20 DDA. These results coincide with those by Gubbels and Dedio (1985) and Stahlman et al. (2010), who also found that the heads and stems dry more slowly than the seeds/grains. The stems presented a higher moisture loss than the heads. When the seeds/grains reached moisture contents suitable for harvest (around 16\% seed moisture), the heads remained with very high 
moisture levels (>65\%), even after applying desiccants (Figures 5 and 6). Head moisture suitable for harvesting as been determined as 50-40\% (Johnson et al., 2002; 2008) Such head moisture level was only reached when the seeds/grains moisture dropped under $10 \%$ (Figures 5 and 6).

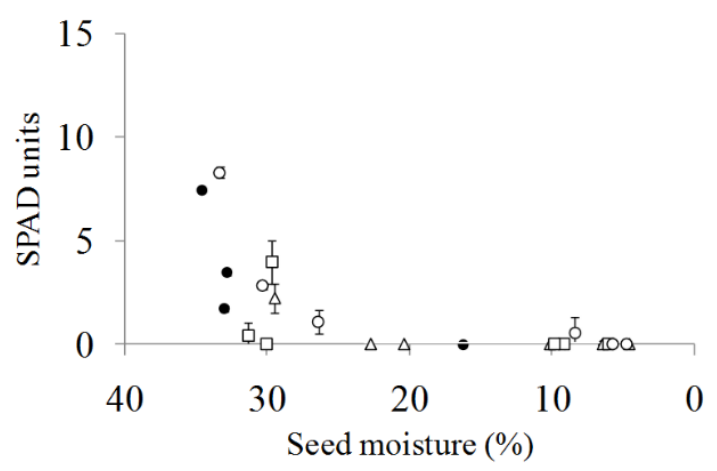

(a)

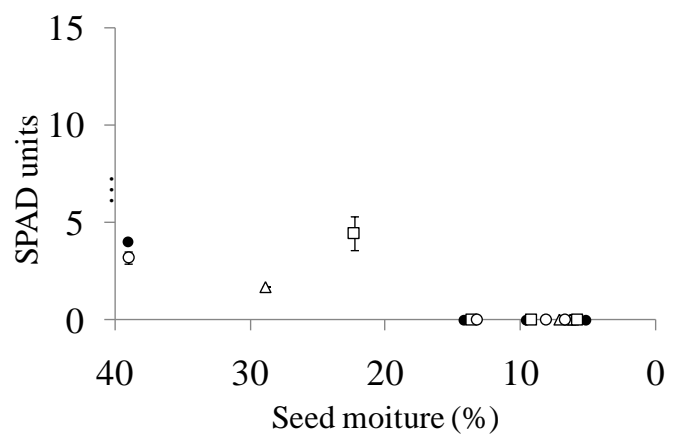

(b)

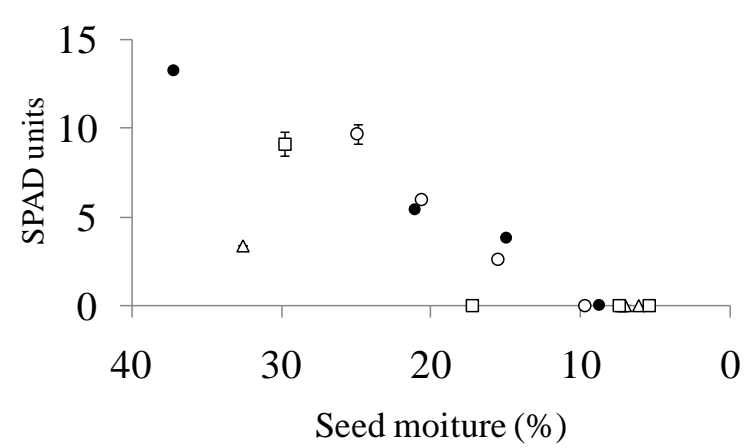

(c)

Figure 7 Dynamics of green coloration of the upper leaves as a function of seed moisture content for sunflower hybrids Paraiso 20 (a), Syn 3820 (b), and

Olisun 4 (c) sprayed with chemical desiccant Paraquat (empty triangle), Saflufenacil (empty square), Carfentrazone (empty circle) and Control without desiccant (black circle) from Exp. 6. Vertical bars indicate \pm 1 SD. Two points differ significantly when the standard error bars do not touch each other.

The advantages of advancing harvest in sunflower crops have been sufficiently documented (Radić et al., 2006, Liovic et al., 2008, Szemruch et al., 2017). However, some questions remain, especially in relation to the reasons why the head presents high moisture even after desiccant spraying. The diversity of environments and genotypes evaluated allows us to infer that the drying of the head did not depend on rainfall, temperature, relative humidity or vapor pressure deficit after the chemical application. However, variables related to the morphology of the head (surface/volume ratio, the amount and conductance of its stomata) or the micro environment surrounding it (intercepting radiation, wind speed or dew point) can widen our knowledge about of the drying of this organ. On the other hand, the vascular connections of the heads and stems with the roots (Hernández and Larsen, 2013) can maintain their water status and mask the effect of the desiccants.

Some visual indicators of desiccation, such as loss of green coloration, leaf detachment, or change in coloration of the head bracts are usually used to decide the beginning of the mechanical harvest after desiccants application (Howatt, 2011, Endres and Hendrickson, 2009). In addition desiccation symptoms may vary according to the active ingredient and organ of the plant in question. Therefore, it is necessary to relate the external symptoms of the plant with the moisture content that each organ effectively has, as the sunflower plant dries down. In this study, leaf coloration loss, was not associated with the moisture loss of the heads or stems, since they remained with moisture higher than $60 \%$ in all the experiments. This corroborates the tendency observed by Stahlman et al., (2010) and forces the search for other indicators capable of distinguishing the appropriate harvest moment in dried crops. Although the desiccants have differences in their modes of action (contact for paraquat and systemic for saflufenacil), they exert the same type of damage with a necrosis of similar size, shape and depth (Fig. 8). The increase in the doses of these products or the use of other desiccants (alone or in combination with each other or with coadjuvants), could improve the response of the heads to desiccation and contribute to increase the efficiency of this technology in plots destined for seeds or commercial hybrids.

Although the drying dynamics of plants may vary between genotypes differing on the speed of leaf senescence (Johnson et al., 2008), in our experiments no differences were observed in the plant drying comparing stay green or non-stay green hybrids. Further experiments, with a broad range of genotypes, will be necessary for identifying possible effects of crop-cycle length, head position, shape and size, on dry-down dynamics of sunflower, especially on the female inbred lines of breeding programs.

Detrimental effects of chemical desiccants on seed germination and vigour were not observed for any sunflower genotype. It was similar to described for Paraquat by Szemruch et al. (2014; 2017). It would be interesting to know if the absence of phytotoxic effects occurs because: i) the active ingredient do not enter into the seeds and it is retained by fruit covers, or ii) it enters into the seed but is detoxified by chemical compounds present in the embryo or the cotyledons. Antioxidant compounds from pea seeds detoxify free radicals and active species of oxygen (Szafrańska et al., 2016). It is possible that the antioxidant compounds of the sunflower pericarp (mainly phenolic compounds) may exert some kind of defence against the action of desiccants. This should be analysed in future research. 


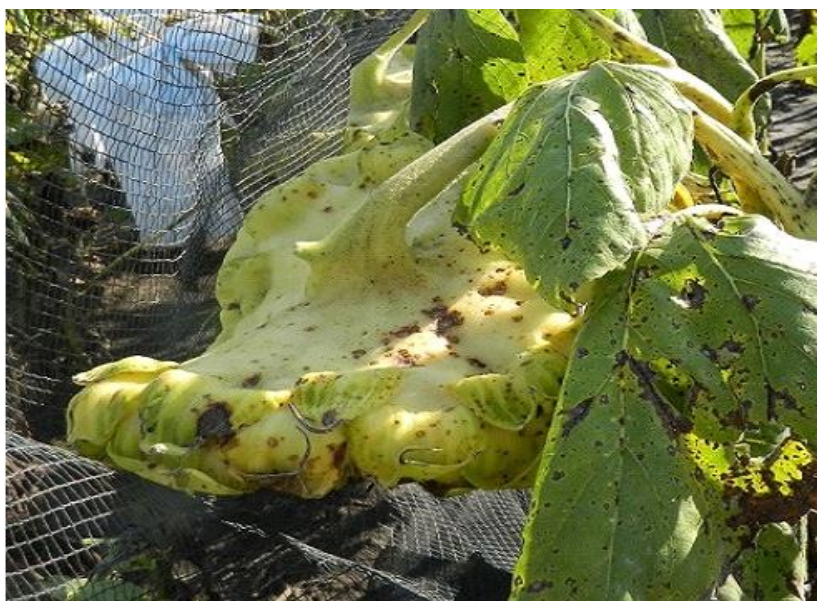

(a)

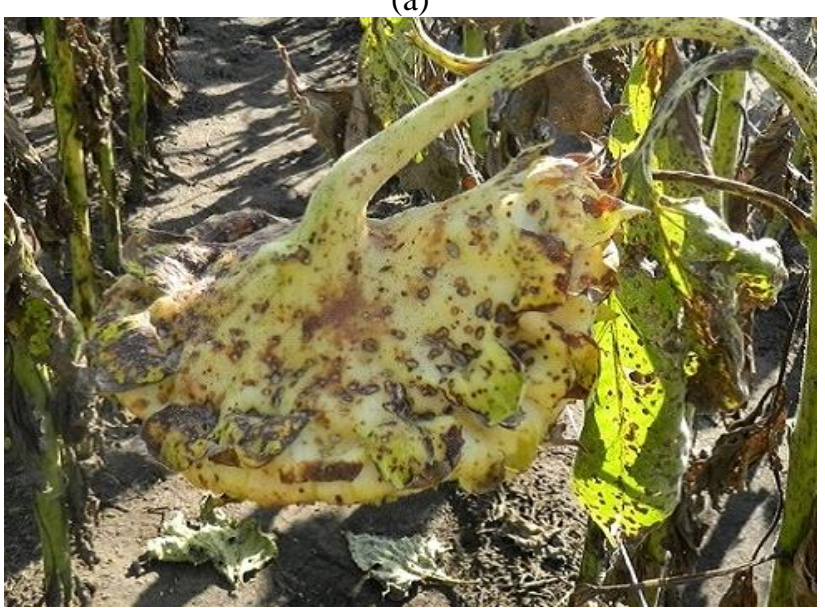

(c)

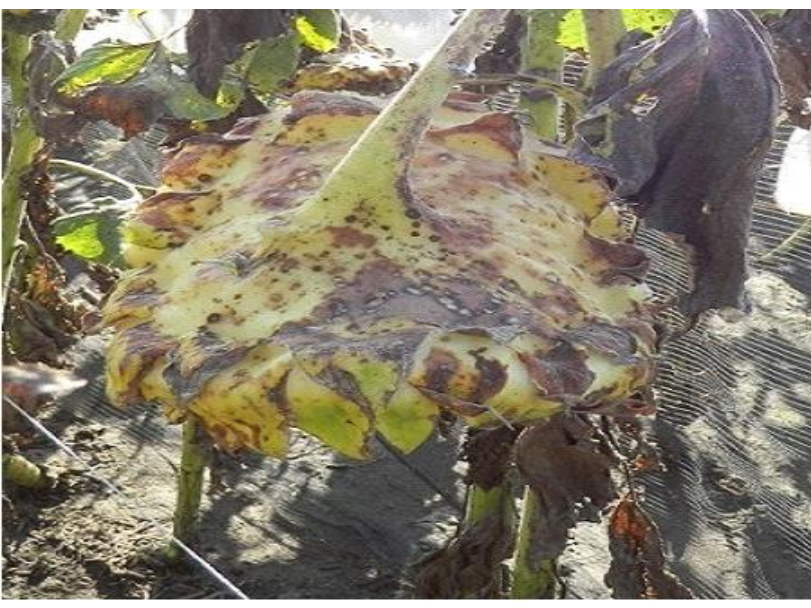

(b)

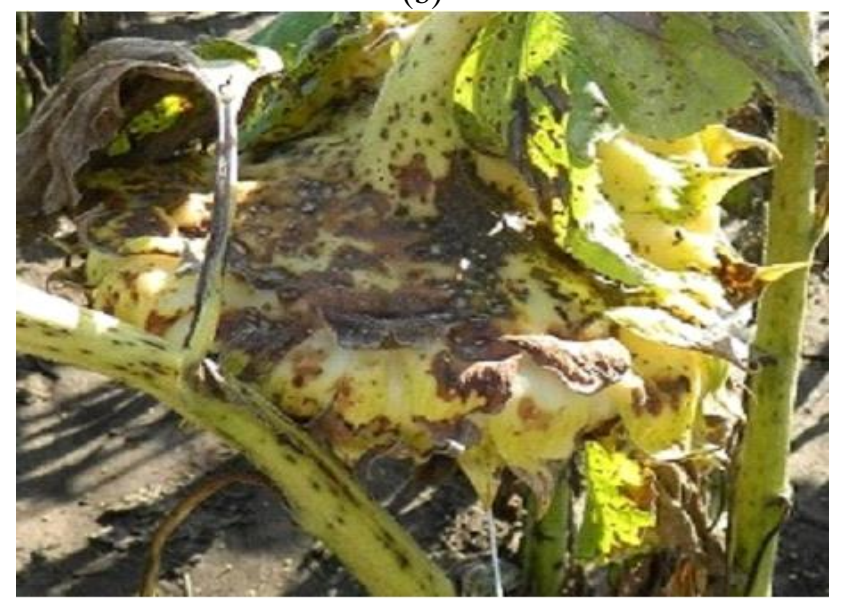

(d)

Figure 8 Images at 6 days after application of Control (a), Paraquat (b), Carfentrazone (c) and Saflufenacil (d) of an oiltype female inbred line from Exp. 1. Note the necrotic lesions caused by chemical desiccants

\section{Conclusions}

Under broad conditions of these experiments, the Paraquat was effective for seeds/grains and stalks drying in both sunflowers hybrids and inbred lines. The slowly drying of heads makes it necessary to continue investigating with new doses and combinations of desiccants to ensure an optimal harvest. Desiccants were safe for seed germination, which benefits their usefulness in the seed industry.

\section{References}

Allen R, Pereira L, Raes D, Smith M. 1998. Meteorological Data, in: FAO - Food and Agricuture Organization (Eds.), Crop Evapotranspiration - Guidelines for computing crop water requirements - FAO Irrigation and Drainage. Rome, Italy. 12.08.2017. Available from: http://www.Fao.Org/Docrep /X0490e/X0490e00.Htm\#Contents

Barry CS. 2009. The stay-green revolution: Recent progress in deciphering the mechanisms of chlorophyll degradation in higher plants. Plant Science. 176 (3): 325-333. DOI: https://doi.org/10.1016/j.plantsci.2008.12.013

Bellé C, Kulczynski SM, Basso CJ, EduKaspary T, Lamego FP, Pinto MAB. 2014. Yield and quality of wheat seeds as a function of desiccation stages and herbicides. Journal of Seed Science, 36 (1): 063-07. DOI: http://dx.doi.org/10.1590/ S2317-15372014000100008
Cumming G, Fidler F, Vaux D. 2007. Error bars in experimental biology. The Journal of Cell Biology, 177 (1): 7-11. DOI: https://doi:10.1083/jcb.200611141

Chaneva G, Petrova D. 2014. Effect of method of applying the herbicide paraquat on pea and maize. 2014. Oxidation Communications, 37(4): 1090-1102.

Chen S, Yin C, Strasser RJ, Govindjee Yang C, Qiang S. 2012. Reactive oxygen species from chloroplasts contribute to 3acetyl-5- isopropyltetramic acid-induced leaf necrosis of Arabidopsis thaliana. Plant Physiology and Biochemistry, 52: 38-51. DOI: http://doi:10.1016/j.plaphy.2011.11.004

Di Rienzo JA, Casanoves F, Balzarini MG, Gonzalez L, Tablada M, Robledo, YC. 2011. InfoStat versión 2011. Grupo InfoStat, FCA, Universidad Nacional de Córdoba, Argentina. Available from: http://www. infostat. com. ar. 8, 195-199.

Denis L, Coelho V, Vear F. 1994. Pericarp structure and hullability in sunflower inbred lines and hybrids. Agronomie, EDP Sciences. 7(7): 453-461. DOI : https://doi.org /10.1051/agro: 19940704

Endres G, Hendrickson P. 2009. Performance of sharpen as a preharvest desiccant in sunflower, Carrington, 2009. North Dakota State University. 11.06.2017. Available from:https://www.ag.ndsu.edu/archive/carringt/agronomy/R esearch/ProdMgmt/2009\%20Sunflower\%20response\%20to $\% 20$ Sharpen.pdf

Esfahani M, Fardi M, Asghari J, Rabiei M, Samizadeh H. 2012. Effects of pre-harvest application of parquat on grain moisture reduction, grain yield and quality of rapeseed (Brassica napus L.) cultivars. Caspian Journal of Environmental Sciences, 10(1): 75- 82 
Fernández V, Bahamonde HA, Peguero-Pina JJ, Gil-Pelegrín E, Sancho-Knapik D, Gil L, Goldbach HE, Eichert T. 2017. Physico-chemical properties of plant cuticles and their functional and ecological significance. Journal of Experimental Botany, 68: 5293-5306. DOI: https://doi:10.1093/jxb/erx302

Franchini1 MC, Lindström LI, Hernández LF. 2008. Epicuticular wax content in the pericarp of sunflower fruits (Helianthus annuus L.) grown under moderate water deficit. Proc. 17th International Sunflower Conference, Córdoba, España, 12.08.2008, pp: 249-253.

Guesh RW, Johnson BL. 2012. Seed moisture at physiological maturity in oilseed and confectionary sunflower hybrids in the northern U.S. Field Crops Research, 133:1-9. DOI: http://dx.doi.org/10.1016/j.fcr.2012.03.012

Gubbels GH, Dedio W. 1985. Desication of sunflower with Diquat. Canadian Journal of Plant Science, 65(4): 841-847.

Grossmann K, Niggeweg R, Christiansen N, Looser R, Ehrhardt, T. 2010. The herbicide saflufenacil (Kixor ${ }^{\mathrm{TM}}$ ) is a new inhibitor of protoporphyrinogen IX oxidase activity. Weed Science, 58(1): 1-9.

Hernandez LF, Larsen AO. 2013. Visual definition of physiological maturity in sunflower (Helianthus annuus L.) is associated with receptacle quantitative color parameters. Spanish Journal of Agricultural Research, 11(2): 447-454.

Howatt K. 2011. Some points to remember about sunflower desiccation. AG Annex 05.01.2017.Available from: http://www.agannex.com/diseases/some-points-toremember-about-sunflower-desiccation.

ISTA. 2013. International Seed Testing Association. International rules for seed testing. Ed. 2013. ISTA. Bassersdorf, Switzerland. ISBN, 978-3-16-148410-0.

ISTA. 2015. International Seed Testing Association. International rules for seed testing. Ed. 2015. ISTA. Bassersdorf, Switzerland. ISBN, 978-3-16-148410-0.

Johnson BL, Larson TD, Henson RA. 2004. Desiccation of staygreen and conventional sunflower. Proc. 16th International Sunflower Conference, Fargo, ND USA. 08.29.2004, pp:213217.

Kleingartner LW. 2010. New weapon in toolbox for sunflower desiccation. The Sunflower Magazine. August/September 2010. National Sunflower Asociation. 08.05.2017. Available from: https://sunflowernsa.com/magazine/articles/default.aspx? ArticleID $=3324$

Linz GM, Bucher EH, Canavelli SB, Rodriguez E, Avery ML. 2015. Limitations of population suppression for protecting crops from bird depredation: A review. Crop Protection, 76: 46-52. DOI: https://doi.org/10.1016/j.cropro.2015.06.005

Liović I, Bilandžić M, Krizmanić M, Mijić A, Popović R, Ivanišić I, Duvnjak T, Šimić B, Ćosić J. 2008. Influence of desiccation on germination and field emergence of sunflower. Proceedings: 17th International Sunflower Conference, Cordoba, España, 12.08.2008, pp. 341-344.

Mantese AI, Medan D, Hall AJ. 2006. Achene structure, development and lipid accumulation in sunflower cultivars differing in oil content at maturity. Annals of Botany, 97(6): 999-1010. DOI: https://doi.org/10.1093/aob/mcl046
McNaughton KE, Blackshaw RE, Waddell KA, Gulden RH, Sikkema PH Gillard CL. 2015. Effect of five desiccants applied alone and in combination with glyphosate in dry edible bean (Phaseolus vulgaris L.). Canadian Journal of Plant Science, 95(6): 1235-1242. DOI: https://doi.org/10.4141/cjps-2014-157

Ongom PO, Volenec JJ, Ejeta G. 2016. Selection for drought tolerance in sorghum using desiccants to simulate postanthesis drought stress. Field Crops Research, 198: 312-321. DOI: https://doi.org/10.1016/j.fcr.2016.03.015

Radić V. 2006. Effect of maturation period on seed quality; optimum time for desiccation in sunflower (Helianthus annuus L.) genotypes. Helia, 29(44): 145-152.

Rondanini DP, Savin R, Hall AJ. 2007. Estimation of physiological maturity in sunflower as a function of fruit water concentration. European Journal of Agronomy, 26(3): 295-309. DOI: https://doi.org/10.1016/j.eja.2006.11.001

Schneiter AA, Miller JF. 1981. Description of sunflower growth stages. Crop Science, 21: 901-903. DOI: https://doi.org :10.2135/cropsci1981.0011183X002100060024x

Schreiber L, Riederer M. 1996. Ecophysiology of cuticular transpiration - comparative investigation of cuticular water permeability of plant species from different habitats. Oecologia, 107(4): 426-432.

Stahlman P, Howatt K, Jenks B, Moechnig M. 2010. Saflufenacil - A new preharvest desiccant of sunflower. Australian Summer Grains Conference. 05.06.2017. Available from: http://www.grdc.com.au/Resources/2010ASGC.

Szafrańska K, Reiter RJ, Posmyk MM. 2016. Melatonin application to Pisum sativum L. seeds positively influences the function of the photosynthetic apparatus in growing seedlings during paraquat-induced oxidative stress. Frontiers in Plant Science, 7: 1663. DOI: https://doi.org/ 10.3389/fpls.2016.01663

Szemruch C, Rentería S, Moreira F, Cantamutto M, Ferrari L, Rondanini D. 2014. Germination, vigour and dormancy of sunflower seeds following chemical desiccation of female plants. Seed Science and Technology, 42(3): 454-460. DOI: http://doi.org/10.15258/sst.2014.42.3.12

Szemruch C, Del Longo O, Ferrari L, Renteria S, Murcia M, Cantamutto M, Rondanini D. 2015. Ranges of vigor based on the electrical conductivity test in dehulled sunflower seeds. Research Journal of Seed Science, 8(1): 12-21. DOI: http://doi.org/10.3923/rjss.2015.12.21

Szemruch C, Cantamutto M, García F, Aguirre M, Renteria S, Rondanini, D. 2017. Hybrid sunflower seed yield, composition and deterioration after chemical desiccation. International Journal of Plant Production, 11(2): 225-238. DOI: http://doi.org/10.22069/IJPP.2017.3421

Toledo MZ, Cavariani C, França-Neto JB. 2012. Qualidade fisiológica de sementes de soja colhida semduas épocas após dessecação com glyphosate. Revista Brasileira de Sementes, 34(1): 134-142. DOI: http://dx.doi.org/10.1590/S010131222012000100017 